\title{
Natural borneol is a novel chemosensitizer that enhances temozolomide- induced anticancer efficiency against human glioma by triggering mitochondrial dysfunction and reactive oxide species-mediated oxidative damage [Corrigendum]
}

Liu WJ, Yin YB, Sun JY, et al. Onco Targets Ther. 2018; 11:5429-5439.

On page 5430, in the "Measurement of ROS generation and Superoxide Anion" section, the sentence “... after treatment with NB and/or TMZ, the cells were incubated with $10 \mu \mathrm{M}$ DCFH-DA or $0.5 \mu \mathrm{M}$ MitoSOX. After reaction, the cells were washed and observed by an inverted fluorescence microscope for the detection of ROS (green fluorescence) and superoxide anion (red fluorescence). The images shown here were obtained from three independent experiments." should read "... cells seeded in six-well plate were pre-incubated for
$24 \mathrm{~h}$ for adherence. Then, the normal cells were incubated with $10 \mu \mathrm{M}$ DCFH-DA or $0.5 \mu \mathrm{M}$ MitoSOX for $15 \mathrm{~min}$ in darkness. Then, cells were stained by DAPI, washed with PBS and treated with NB or/and TMZ for $1 \mathrm{~h}$. ROS (green fluorescence) and superoxide anion (red fluorescence) were observed by an inverted fluorescence microscope. The images shown here were obtained from three independent experiments."

On page 5433, Figure 2B, an error was made during the experimental design and the control group was not treated with NB for superoxide anion generation. The updated Figure $2 \mathrm{~B}$ is as follows:

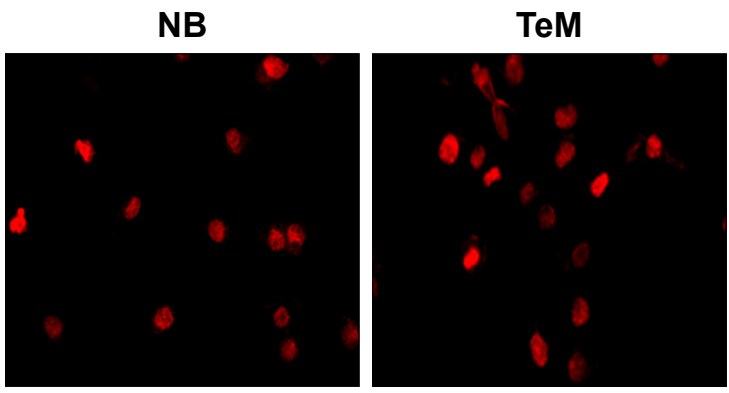

On page 5433, Figure 2C, two images were inadvertently duplicated, the control group and NB-treated group both showed no cell apoptosis. The updated Figure $2 \mathrm{C}$ is as follows:

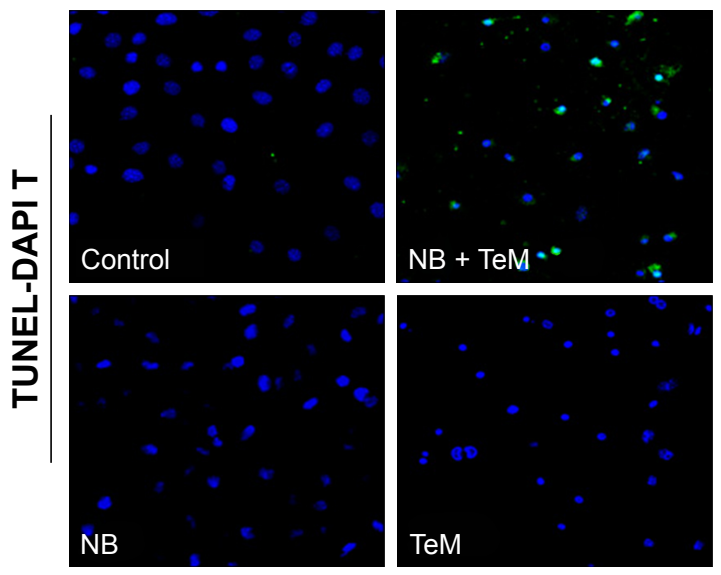


On page 5435, Figure 4B, an error was made during the experimental design and the control group was not treated with NB for superoxide anion generation. The updated Figure $4 \mathrm{~B}$ is as follows:

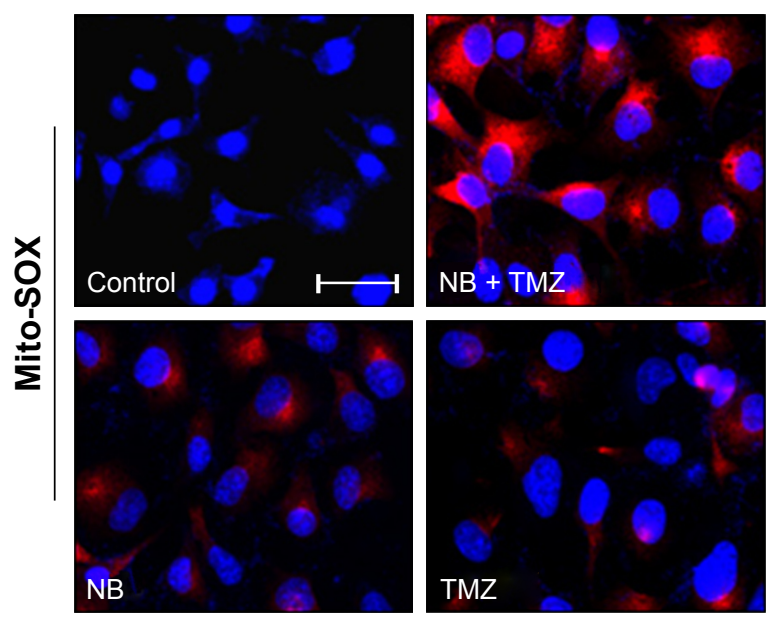

\section{Publish your work in this journal}

OncoTargets and Therapy is an international, peer-reviewed, open access journal focusing on the pathological basis of all cancers, potential targets for therapy and treatment protocols employed to improve the management of cancer patients. The journal also focuses on the impact of management programs and new therapeutic agents and protocols on patient perspectives such as quality of life, adherence and satisfaction. The manuscript management system is completely online and includes a very quick and fair peer-review system, which is all easy to use. Visit http://www.dovepress.com/testimonials.php to read real quotes from published authors. 